\section{Kentsel ve Kolektif Belleğin Sürekliliği Bağlamında Kamusal Mekanlar: ULAP Platz Örneği, Almanya}

Işıl Ekin ÇALAK

Bahçeşehir Üniversitesi,

Mimarlık ve Tasarım Fakültesi, Mimarlık Bölümü

Bugün bellek kavramına ilişkin çalışmaların, daha çok disiplinlerarası bir tarıışma alanında yer aldıkları görülmektedir. Özellikle 19. yy sonu ve 20. yy başında farklı displinlerden yaklaşımların ardarda gelerek birbirini olgunlaştırması, bellek kavramının bugün anladığımız ve çalıştığımız biçimde sorunsallaştırılmasına zemin hazırlamıştır.

Bellekle ile yorumlarının bugün hala geçerliliğini koruduğu Sigmund Freud (1856-1939)'a göre, bellekle birebir ilişkili olan hatırlama ve unutma pratikleri, bireysel seçimlerin sonucudur. Bilinçaltının hatırlamak istenmeyenleri bastırmasıyla unutma gerçekleşir. Bu, aynı zamanda, 'ego'nun kendini savunmasının, dolayısıyla kişinin kendini korumasının bir yoludur. Tüm bu süreçte Freud belleği 'bireysel' olarak yorumlamıştır. Henri Bergson (1851-1941) ise, aynı dönemde belleği, algılama sonrasında gerçeği temsilen zihinde oluşan imgeler üzerinden yorumlar. Bergson'a göre algılama, kültürel, psikolojik etkiler altında gerçekleşir ve kişiye özgün imgelem dünyası da yine bu etkiler altında oluşur. 'Kolektif Bellek' kavramıla bu alanda yeni bir dönem başlatan Bergson'un öğrencisi Maurice Halbwachs (1877-1945), hocasının ve Freud'un çalışmalarını tam da bu noktadan sonra ileriye taşımaktadır.

Halbwachs (1992, 52-53)'a göre bellek, her ne kadar kimi zaman 'bireysel bir hatırlama'ya referans verse de, her zaman sosyal kodlara göre oluşur. Bellek, toplum tarafından üretilen kolektif bir oluşumdur ve dolayısıyla bu oluşum 'kolektif bellek' olarak adlandırılmalıdır. Halbwachs'a göre, Freud ve Bergson'un tartıştığı biçimdeki bireysel bellek, bireyin içinde bulunduğu sosyal ve fiziksel çevre olmaksızın tariflenememektedir. Bellek, her şekilde toplumsal, kolektif bir üretimdir.

Halbwachs'ın bu yaklaşımı, şehir plancıları ve mimarlar için, birçok disiplin alanında olduğu gibi yeni tartışmalara zemin hazırlamıştır. Belleğin toplumsal olduğu öngörüsü, bireyin yapılı çevre ile etkileşimini bellek bağlamında irdeleyen yeni bakış açılarına olanak sağlamıştır.
Öz

20 .yy.'da hız kazanarak değişen yaşam biçimlerimiz, yaşamlarımızın geçtiği mekanları da hızlı biçimde değiştirmektedir. Bu hızlı dönüşüm, insanların geçmiş ile bugün arasındaki dinamikleri daha fazla sorgulamasına sebep olmuş, bu da bellek, kimlik, aidiyet gibi kökenlere ve kültürlere ilişkin araştırmalarda fark edilir bir artışa yol açmıştır. Bu çalışmalardan bellekle ilgili olanların bir kısmı "bellek ve mekan" ilişkisine odaklanmış ve bizlere kent ve mimarlığa ilişkin birçok yeni perspektif kazandırmıştır. Bu makale, belleğin mekanla kurduğu pek çok ilişkinin yanısıra, birbiri üzerinden türettiği bir süreklilik ilişkisi içerisinde olduğunu, Berlin'den verilen bir örnek üzerinden göstermeyi amaçlamaktadır.

Berlin' in bugünkü Mitte bölgesinde yeralan "ULAP Platz" projesi, kentsel ve kolektif bellekte varolan kırılmaları onararak, yeniden sürekliliğini sağlamadaki başarısı sebebiyle bu metin kapsamında örneklendirilmiştir. 2008 yılında uygulanmış olan proje, 2010 yılında "Avrupa Kentsel Kamusal Alan Ödülü”nü (The European Prize for Urban Public Space) almıştır.

Abstract

Since the beginning of 20th century there has been a rapid change in the built environment as well as the lifestyles. This change evokes people to question more about the past and there has been growing interest in research about the issues of cultural origins and heritage such as memory, identity and belonging. Among these research, some has looked into various relations between memory and space but additionaly, this paper focuses on one further relationship between them; the continuity. This paper aims to underline this relationship through the analyses of ULAP Platz Project established in Berlin City. After its establishment in 2008, the ULAP Platz Project in Berlin, has been awarded "The European Prize for Urban Public Space" in 2010 because of its remarkable sensitivity on urban and collective memory. The history which the project carries from the past to the future and its manner towards the continuity of urban and social memory are the reasons of why it is a appropriate and fertile example for this paper.

\section{Anahtar Kelimeler:}

Kentsel bellek, kolektif bellek, belleğin sürekliliği, kamusal alan.

Keywords:

Urban memory, collective memory, continuity of memory, public realm 


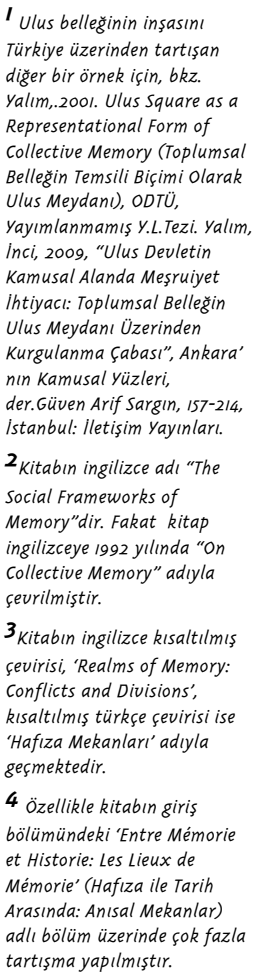

Aldo Rossi, 1960'larda yazmış olduğu "Şehrin Mimarisi" adlı kitabında kolektif belleğin, mimarlık ve kenti oluşturan her türlü değer ile ortak birlikteliğinden bahsetmektedir. Bir mimar olarak Rossi'nin belleğe ilişkin tanımları, Halbwachs'a göre daha mekansaldır. Rossi (2006, 121 126)'ye göre, kentin kendisi orada yaşayanların kolektif belleğidir. Kente ilişkin her parça, kentin kendisini ve belleğini içinde barındırmaktadır. Bunun yanısıra, insanlar arasındaki sosyal ilişkiyi mekansal olarak görünür kılmaktadır. Rossi'ye göre kenti oluşturan mimariler, mekanları üzerinden üretilen sosyal ilişkilerle kent belleğinin bir parçası haline gelmekte, bu ilişkiler ağı kentin tarihi içinde akarak zamanla onu biçimlendirmekte, yeniden üretmektedir. Rossi, kolektif belleği kente içkin ve onunla bir bütün olarak görürken, kentin yaşayan bir organizma gibi canlı bir ‘öz’e sahip olduğunu da iddia etmektedir. Mekanlar inşa edildikten sonra zaman içerisinde orada bir 'genius loci' gelişmektedir. 'Yerel tanrı' olarak da adlandırdı ̆̆ı bu öz, başka kaynaklarda 'kentin ruhu' olarak geçen kavramla da benzeşmektedir. Bu öz sayesinde, kenti yaşayan bir organizma gibi 'canlı' tahayyül eden Rossi, dolayısıyla kent ve mimarlığı belleğin öznesi olarak yorumlamıştır. Yerin, zaman içerisinde biriktirdiklerinin, onun anlamını ve ruhunu oluşturduğunu iddia eden bu tür yaklaşımlar, kent ve mimarlıklar üzerinden oluşan kolektif belleğin yanısıra, kendisinin de bir belleği olduğunu açıklamaktadır. Kente ait bu bellek, 'kentsel bellek' kavramsallaştırmasıyla literatürde yerini almaktadır.

1970'lerde, postmodernizmin etkisiyle başlayan tarihyazımı tartışmaları bellek konusunda da başlayan yeni bir dönemi işaret etmektedir. II. Dünya Savaşı'nın ardından, geçmişe ve tarihe ilişkin öğretilerin gerçekliğine duyulan şüphe, toplumlara ilişkin belleğin de, ideolojik olarak üretilmiş, koşullara uygun bir biçimde her defasında yeniden yapılandırılmış, manipüle edilmiş olduğu görüşünü iddia etmiştir. Özellikle I. Dünya Savaşı' nın ardından, ulus-devletlerin yapılanmalarında görülen yoğun milliyetçilik söylemleri, bir ulusu vareden milli güçlere ilişkin eğilimleri de derinden desteklemekteydi. Bu yapılanmalar sırasında ihtiyaç duyulan "biz"in tarifi için, ortak bir bellek fikri ve inancı büyük önem taşımaktaydı. Ulusu aynı ülküde birleştirecek ortak bilinç, omuz omuza kazanılan zafer ve başarılar, belli nedenlere dayandırılan biriciklik iddiaları gibi tüm otarşik söylemler o dönemde ön plana çıkmıştı. Bunların mekansal her türlü temsili de dolayısıyla anıtsallaştırılarak, kutsanma eğilimindeydi. Böyle bakılınca yapılı çevre üzerinden oluşturulmaya çalışılan ortak bir ulus belleği, ideolojik olarak üretilmiş yeni bir dil ortaya çıkarıyordu ' .

Belleğin, geçmişin farklı biçimlerde kurulmasıyla, üretilebilir olduğu tezine, her ne kadar Halbwachs 1925'deki 'Les Cadres Sociaux de La Mémoire' (Belleğin Sosyal Çerçevesi) ${ }^{2}$ adlı eserinde değinmiş olsa da, 1984'de Pierre Nora yedi ciltlik eseri

'Les Lieux de Mémoire' (Anısal Mekanlar) ${ }^{3}$ içerisinde bu duruma, kent ve mimarlık üzerinden somut örnekler vererek, önemli tartışmaların başlamasına neden olmuştur ${ }^{4}$. Nora, toplumsal yapının, geçmişle ilişkilerinin kentin biçimlenişine etkilerini, Fransa Ulusal Tarihi üzerinden yeniden sorgulamıştır. Nora’ya göre, modern toplumların geçmişe ilişkin belleklerinde yer alan içsel bilgileri olmadığı için, onu ancak bugün içierisinde yeniden kurarak - 'anısal mekanlar' (lieux de 
mémoire) oluşturarak- anlamaya çalışırlar. $\mathrm{Bu}$ şekilde, geçmişle yaşanılan zaman arasında, kırılmış olan süreklilik duygusunu yapay olarak yeniden kurmaya çalışmaktadırlar 5 . Halbuki, geri getirilemeyecek olan bir zamanı, bugün yeniden inşa etmek, zamana ilişkin hakikati gözden kaçırmak demektir. Fakat kendini hala kökleriyle, geçmişiyle tarif eden bilinç, geçmişin bugün de yaşıyor olduğuna da inanma eğilimi gösterecek, hatta buna ihtiyaç duyacaktır.

Nora'dan sonra mimarlık, kent ve bellek ilişkisine dair yapılan diğer bir önemli çalışma ise Christine Boyer'in 1998 yılında yayınladığı "The City of Collective Memory" adlı kitabıdır. Boyer eserinde, kolektif bellek bağlamında hatırlama ve unutmanın, gündelik pratiklerle ve yapılı çevre ile doğrudan ilişki içerisinde olduğunu anlatır ${ }^{6}$. Ona göre günümüzde hatırlamak, herşeyin hızla değiştiği dünyada, daha da önemli hale gelmiştir. Kitabında da geçmiş ile bugün arasında kurulan ilişkileri ve dengeleri sorgular. Boyer, kentlerdeki kamusal alanların, kolektif bellek ve kentsel kimlik için önemi ve belirleyiciliğine büyük önem vermiştir.

Kamusal alanlar, geçmiş, bugün ve gelecek arasında kurulan ilişkilerin en kritik bağlayıcı noktalarıdır. Geçmiş ile kurulan ilişki, gelecek ile kurulacak ilişki için de referans noktaları oluşturur. Dolayısıyla, bu alanlar kentler için kimlik kurucu noktalar olmasının ötesinde, o toplumun kolektif belleğini ve kentlilik bilincini yansıtan, özgün yaşam alanları olarak ortaya çıkmaktadırlar.

Madanipour (2010, 1-15), 'Whose Public Space' (Kamusal Alan Kimin) adıyla derlediği kitabının giriş metninde, kamusal alanların tasarım ve gelişiminin kentler için neden bu kadar önemli olduğunu sorar. Cevabı ise çok basittir; "Kamusal alanlar sokaklar, caddeler, parklar, meydanlar kentsel hayatın geçtiği yerlerdir".

Kamusal alanların, bir toplumun oluşmasında çok önemli rolleri vardır 7 . Kamusal alanlar yukarıda da sözünü ettiğimiz gibi bir toplumsal karşılaşmanın mekanıdır, eşitlik koşulların paylaşıldığ kolektif belleğin üretildiği ya da bu bilincin gelişebildiği yerlerdir. Daha çok toplumun diğer üyeleriyle yüzyüze gelme, kendini tanıma, toplumunu tanımlama yeridir. Bunun dışında kentsel deneyim, tanıdık olmayana karşı hoşgörünün geliştiği, bilinmeyenlerle karşılaşma durumudur. Bu tür kentsel deneyimler hem kolektif bilinci beslemekte hem de birlikteliğe olan duyarlılığı artırmaktadır.

"Bugün toplumlar ve kültürel pratikler yalnız kente ilişkin olmayan inanılmaz bir kültürel bir akıştan, dolaşımdan beslenirler. Bunlar kitaplar, dergiler, reklamlar, müzik, resim, sergiler, çeşitli teknolojik ekipmanlar gibi sayılamayacak kadar çoktur. Kentler, elbette ki, bu dolaşımın toplumlara ulaştığ 1 bir duraktır, fakat tüm bu akış yalnız fiziksel olanaklara ya da biçimlenişe göre tariflenemeyecek kadar karmaşık, tek kaynak gösterilemeyecek kadar çok yönlü ve katmanlıdır." (Amin 2006). Yapılan birçok çalışma, kentsel kamusal alanlara bir kültür pratiği ve politik bir vizyon olarak yaklaşmıştır. Fakat günümüzde artık, kültürün biçimlenişine etkiyen ve politik pratikleri değiştiren o denli hızlı ve kaygan bir zemin vardır ki, artık kente ve topluma ilişkin iddialarda eskisinden çok daha fazla kavramı tartışmak gerekmektedir. Kentler, tarihsel arka planlarıyla ayrıştırılamayacak birçok parçasıyla, farklı deneyimlere olanak

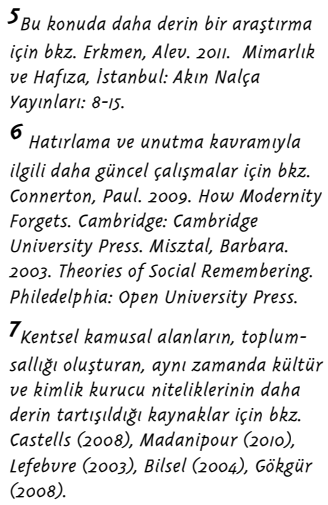


sağlarlar. Dolayısıyla bir kentin geçmiş izleri üzerinden türeyen her bir hikaye için, onu deneyimleyenin özgün bir anlam üretmesi çok olasıdır. Musil (1998, 320), "Dünyada anıtlar kadar görünmez yapılar yoktur" der. Anıtlar, o denli deneyime kapalıdır ve özgün düşünce ve duygu üretmeye imkan sağlamazlar ki, bir süre sonra fiziksel varoluşları dışında sessizliğe bürünür, ifadesizleşirler. Zamana karşı koyamaz, insanla ve yaşamla birlikte devinemezler. Belleğe ilişkin bu türden anıtsallaştırmalar, kentler üzerinden öğrenilecek kültürel pratiklerin edinilmesinin önünde de birer engel oluştururlar. T1pkı Adorno (1991, 52-54)'nun 'metalaşmış kültür'den anımsattığı gibi, onlar da dondurulmuş belleklere, üretilmiş anılara dönüşürler.

Modernizm, 19. yy. boyunca, kente ve mimarlığa ilişkin tüm sorunların ancak rasyonel bir planlama yaklaşımıyla giderilebileceği inancına dayanmıştır. 20 . yy.'da, savaştan çıkmış şehirlerin, değişen toplumsal, ekonomik ve politik süreçlerine ve bunlarla yeniden harmanlanmış yapılarına karşın, modernizmin evrensel doğrular oluşturan çözücü, ayrıştırıcı eğilimi, bazı sorunları çözerken, bazı sorunları derinleştirmiştir (Bilgin 1995, 8990). İlerleyen bölümlerde daha geniş yer verilecek olan ULAP Platz (ULAP Meydanı) Projesi' ise, modernizmin getirdiği bu müdahaleci tavrı aşan yorumu ile 20. yy.' 'n belki de en derin izlerini bıraktığı Berlin'de, bugün yerle olan bağlarını yeniden kurma çabasıyla, yerine ve tarihine ilişkin kendine özgü çözümlerini üretebilmiş doğru örneklerden biri olarak gösterilebilir.

$\boldsymbol{U L A P}$ (Universum-Landes-Ausstellungs-Park) ${ }^{8}$

Platz Projesi, Berlin

Berlin, bölünmenin, birleşmenin, faşizmin, boşluğun ve bunların derin izlerinin ardından tekrar tekrar yazılan bir metin gibidir. Çağdaş kent, mimarlık, kimlik, bellek, unutma ve hatırlama üzerinden her defasında başka türlü yazılabilecek büyük ve zor bir hikayedir. Temsil ettiği geçmiş hikayesini bugüne yalnızca sunmakla kalmiyor, diğer her değeriyle birlikte yaşamaya devam etmektedir. Dolayısıyla, Berlin, artık yaralarını sarmanın ötesinde, Ulap'da getirdiği gibi özgün ve ezberbozan yorumlarıyla da gelecekteki kentsel tasarım yaklaşımlarına ışık tutmaktadır.

Berlin, özellikle 19. yy. ardından geçirdiği travmatik dönemlerde, kente ve kentlilere ilişkin büyük kayıplar vermiştir. Bu kayıplar nedeniyle, geçmişe ilişkin katmanlar o denli hırpalanmıştır ki, kent zamana ilişkin bütünselliğini büyük oranda yitirmiştir. Tanyeli (2002, 1-2), bu yüzden Berlin'i, kimliksiz ve kent olma 'aura'sından yoksun bulur. Tanyeli'ye göre bu çok parçalı ve birbirinden kopuk oluş hali, kentte hissedilmek istenen mekansal ve tarihsel sürekliliği bozguna uğratmaktadır. Ayrıca, kent denilen yerleşme, ancak mimari anlama kentsel bir içerik, bir doya doya yaşanmışlık ve tüketilmişlik duygusu verdiği zaman bir varlık kazanabilecektir. Tanyeli'ye göre, Berlin'de neredeyse hiç bulunmayan budur.

Tanyeli, Berlin'de hissedemediği bir yaşamsal süreklilik ve kent belleğindeki kırılmadan bahseder. Soğuk Savaşın ardından bir şantiyeye dönen Berlin, kısa zamanda bir metropol haline gelmiştir. Varolan ve yokolanlar Berlin'in bir kaderi de olsa, bugün, Berlin; geçmiş, bugün, hatta gelecek arasındaki dengeyi oluşturabilmek adına, kentsel ve kolektif belleğe ilişkin çoğu politikanın birarada görülebildiği, bu konuda oldukça fazla tartışma alanına sahip, verimli bir coğrafyadır. 
Berlin'de, I. Dünya Savaşı'nın ardından milliyetçi politikaları destekleyen 'bellek inşası'na dair mekansal örgütlenmeler, II. Dünya Savaşı sonrasında büyük eleştirilere maruz kalmıştır. Milliyetçilik söylemlerinin aşırı uçta kullanımlarına (ırkçılı̆̆a ve soykırıma) karşı gelişen tavır, onlara ait domine edici ve tekil temsillerinin de yıkılarak unutulmak istenmesine yol açmıştır. Zaferin ya da savaşın; ideolojik mesaj içeren her türlü düşüncenin anıtsallaştırması fikri büyük bir tepki oluşturmuş̧ur. Savaşın hemen ardından yaşanan durgunluk ve soykırımın hiç yaşanmamış olduğu varsayımı ${ }^{9}$ Berlin Duvarı'nın yıkılışıyla, bellek konusunda tekrar bir dönüşüme yol açmıştır. 'Bellek Patlaması' 10 da denilen bu dönemde müzeler, arşiv mekanları, dokümanter kaynakların sayısında büyük bir artış yaşanmıştır. Belleği dış kaynaklara emanet eden ve onu gündelik yaşamdan sildiğine inanan tartışmaların yanısıra, her türlü tarih kurucu söylemin karşısında duran ve yorumu olayın geçtiği mekanı deneyimleyene bırakan, dolayısıyla kullanıcıyı pasifize olmaktan çıkaran yaklaşımlar öne çıkarmaktadır.

ULAP Bölgesi, tam da Tanyeli'nin Berlin'de bulamadığı sürekliliği yeniden kurmaya çalışan bir örnek olarak Berlin için, kendi gibi niceleriyle birlikte önemlidir. ULAP, kentin merkezinde yer almasının ve kentin tarihine ilişkin bir çok hikaye barındırmasının yanısıra, bu hikayeleri yeniden kurması ile değil, bu hikayelerle yıllar sonra yeniden ilişki kurması ile anlamlıdır. Birleşmenin ardından, yıllarca Berlin'in merkezinde kayıp bir boşluk olarak durmuş olsa da, belleğinde varolan bu kırılmayı onararak onu tekrar tarihsel bir süreklilik hattına bağlayabilmiş olması projenin, 2010 yılında "Avrupa Kentsel Kamusal Alan Ödülü”ne (The European Prize for Urban Public Space) layık

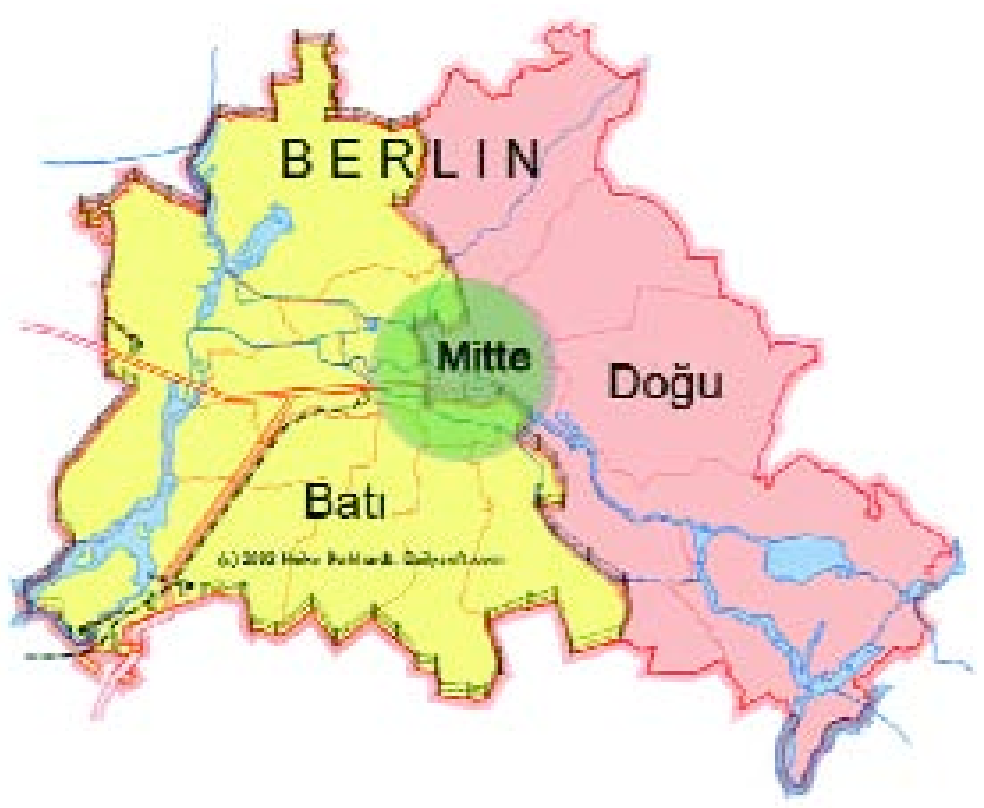

görülmesiyle sonuçlanmıştır. 2008 yılında tamamlanmış olan ULAP Platz Projesi, bölgeye ilişkin tasarımlarındaki kentsel ve kolektif bellek bağlamında yorumları nedeniyle bu çalışma kapsamında örneklendirilmektedir.

\section{Proje Alant}

Mitte bölgesi, bir yandan şehrin en göz alıcı bulvarlarından Unter der Linden'i bir yandan da zamanında en sıkı sınır geçiş önlemlerinin alındığı noktalardan biri olan Checkpoint Charlie'yi içine alan, eskinin doğu ve batısından izleri birlikte taşıyan Berlin'in en kritik noktalarından biridir. Tarihi Reichstag binasına taşınan federal parlamento ve birçok milletvekili ofisiyle ülkenin önemli politik odaklarından da biri olmuştur. Bunun yanısıra, Spree Nehri'nin üzerinde bulunan 'Museuminsel' (Müze Adası) adındaki 1 kilometrekarelik alana sahip adada yeralan müzeler kompleksinde, UNESCO'nun Dünya Mirası listesinde bulunan çok değerli eserler sergilenmektedir. Brandenburg Tor (kapısl), Potsdamer Platz (Meydanı) ile ULAP Platz'ın yeraldığı Berlin Hauptbahnhof
${ }^{9}$ Soykirımin savașin hemen ardindan yadsınma eğilimi için, bkz. Levi, Primo. 1996. Boğulanlar Kurtulanlar. Istanbul: Can Yayınları. Kirshenbaum, Binnie. 2004. Hester Yikintılar Arasında. Istanbul: Agora Kitaplığı.

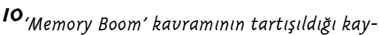
naklar için, bkz.Beiner, Guy.2008. In Anticipation of a Post-Memory Boom Syndrome. Cultural Analysis 7. Huyssen, Andreas. 1995. Alacakaranlik Anıları: Bellek Yitimi Kültüründe Zamani Belirlemek. Istanbul: Metis Yayınları, 11-21. ume7/vol7_discussı.html" [10.04.2012]; Winter, Jay. "The Memory Boom in Contemporary Historical Studies," Raritan 21// (summer 2002): 52-66; Berliner, David C. "The Abuses of Memory: Reflections on the Memory Boom in Anthropology". Anthropological Quarterly 78/1: (Winter 2005): 197-211; Eric Langenbacher and Friedenke Eigler. "Introduction: Memory Boom or Memory Fatigue in 21st Century Germany" German Politics and Society 23/3: (Fall 2005): 1-15. "http://socrates.berkeley.edu/caforum/vol - 
Resim: 2 Resim: 2 .19.yy'da Ulap Fuar Alanı'na ilişkin görseller.

Kaynak: URL-I

Resim: 3

19.yy.' da Ulap Fuar Alanı'na ilişkin görseller

Kaynak: URL-I

Resim: 4

19.yy' da Ulap Fuar Alanı'na ilişkin

görseller

Kaynak: URL-I
(Ana Tren İstasyonu) da bu alanda bulunmaktadir.

ULAP Platz, Hauptbahnhof'un batısinda kalan üçgen parselde yeralmaktadır.

ULAP Meydanı sayesinde, Alt-Moabit

Bulvarı'ndan tren istasyonuna kısa yoldan ulaşılabilmektedir. 2008 yılında uygulanan tasarımla bu geçiş, güvenli ve yeşil bir hat haline gelmiştir.

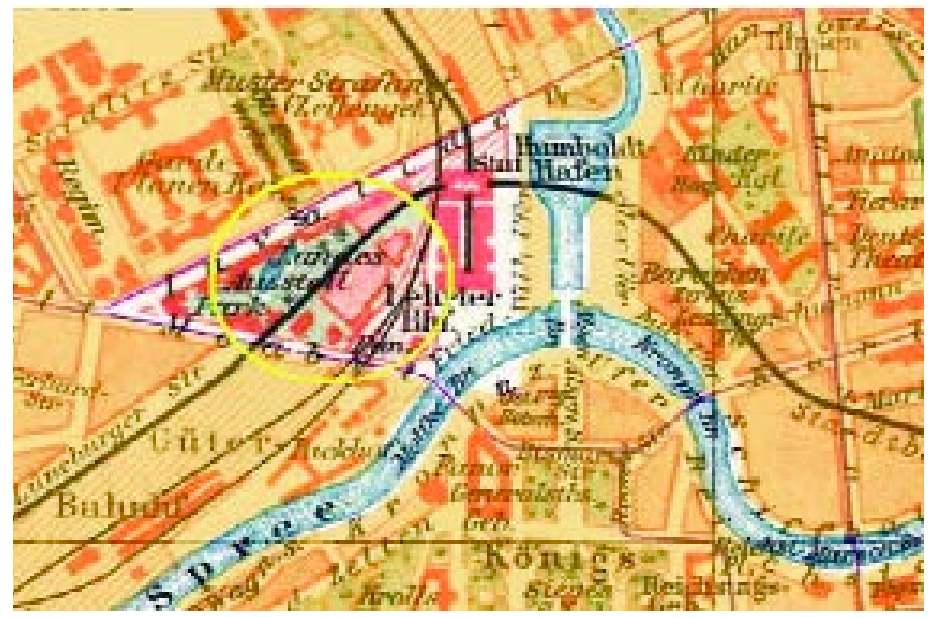

Resim: 2
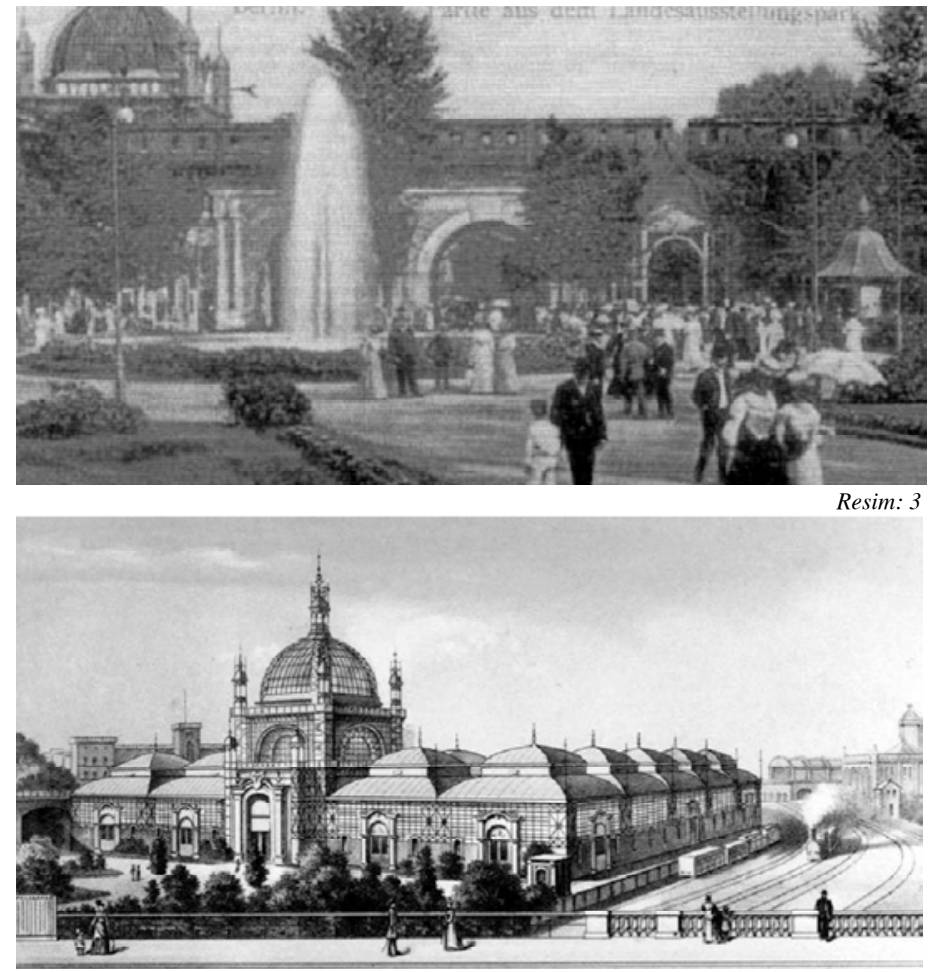

\section{Alanın Tarihi}

1879'da 19. yy.'in yeni hevesi olan Dünya

Fuarları'nın heyecanı Avrupa'yı sardığında, Berlin'de Universum-LandesAusstellungs-Park (ULAP) adında bir fuar bölgesi inşa edilir. Bugün Berlin'de turistlerin en fazla ilgisini çektiği, birçok müzenin ve önemli yapının bulunduğu Mitte bölgesinde, Alt-Moabit Bulvarı ve Invalidenstraße (Caddesi)'nin kesiştiği üçgen parselde yeralan fuar alanı, Spree Nehri ile Reichstag Bölgesi'nden ayrilır. 1961-1990 yılları arasında Doğu Berlin kısmında kalan alan, biraz ilerisinde yer alan Lehrter Tren İstasyonu'na giden demiryolu viyadüğü ile de algısal olarak ikiye bölünmektedir.

1879 'da hijyen, sanat ve teknoloji üzerine uluslararası endüstriyel bir fuarla halka açılan alan, 1883 yılında zamanın tavrına uygun biçimde cam ve çelik strüktürden inşa edilen yeni binasıyla "Büyük Berlin Fuarı” adını almıştır. I. Dünya Savaşı'na kadar sergi ve fuar alanı olarak işlevini sürdüren bina, savaş yıllarında cephanelerin ateşleyici fitillerinin üretildiği bir yer olarak kullanılmıştır. Savaş sonrasında, 1925 yılına dek, alanın halkın modern dünyanın ürünlerini kutladığı bir eğlence ve dinlenme alanı olarak kullanıldığı bilinmektedir (URL-1).

"Savaş ve savaş sonrası dönemde, önemli toplumsal, ekonomik ve politik dönüşümler geçiren ülke, tüm bu değişimlerle birlikte ideolojik olarak da sarsıntılar yaşamıştır. Büyük şehirlerin daha da büyümesine, küçüklerin ise kaybolup gitmesine neden olan sistem, kalan büyük sanayi şehirlerinin de daha iyi planlanmasını dayatmıştır." (Schubert 1995, 99107). Toplum ve devlet adına ortaya atılan yeni fikirler, daha demokratik, hümanistik eğilimler gösterirken, yeni teknolojinin 
sağladığı olanaklar halka daha fazla sunulmakta, bu da kentteki ulaşım ve altyapı çalışmalarına hız katmaktadır.

Bu gelişmeler doğrultusunda, 1926 yılında, bugün halen alanın $4 \mathrm{~m}$. yükseliğinden geçen ve onu ikiye ayıran demiryolu hattının inşasına başlanmıştır. Fakat yapılan kazılar, dehşet verici bir gerçeğin ortaya çıkmasıyla bir süre durdurulmuştur. Bölgenin yakınlarında bulunan Moabit Hapishanesi'nde, 1919 yilında öldürülen onlarca Spartaküs Birliği"' tutuklusunun kemikleri bu kazılarda gün 1Ş1 ğına çıkmıştır (Kalcher ve Schröder 2009, 8492). Bu olaydan sekiz yıl sonra, 1934

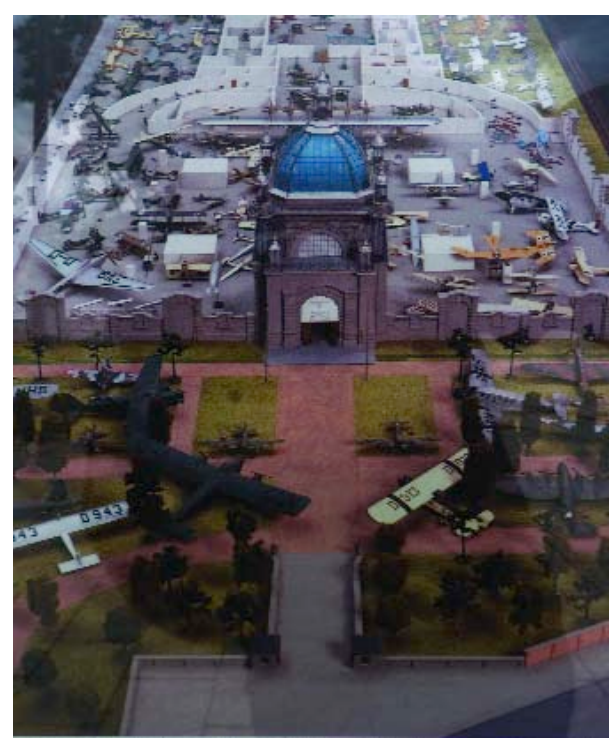

Resim: 5

yılında Sergi ve Fuar Binası, Alman Havacılık Müzesi'ne çevrilenene kadar, bölge pek kullanılmayan bir alan olarak kalmıştır.

Bina müzeye dönüştürüldükten sonra ULAP Bölgesi, Nazilerin gençlik kollarının cam ve çelikten olan müze binasının restoran işletmesini almasıyla, bir üs olarak kullanılmaya başlamıştır. Burası birkaç ay içerisinde, Nazilerin konsantrasyon merkezi olarak kullandıkları bir alana dönüşmüştür (Kalcher ve Schröder
2009, 84-92). 1933-1943 yılları aras1, bölgenin kara günleri olarak anılır (Pearson 2011, 8). Bu dönemde burada çok fazla katliam yapılmıştır. Birçok aktif sosyal demokratın kaçırılarak burada aylarca işkence gördüğüne ve öldürüldüğüne dair bugün birçok rapor bulunduğu belirtilmektedir. O dönemde avukatlık yapan Werner Rosenstock, bir gün sebepsiz yere tutuklandığ 1 fakat yahudi olduğu için, hapishaneye değil, ULAP Müze Binası'nın bodrum katına götürüldüğünü anlatır. Orada şahit olduklarını şu sözlerle aktarmıştır: " ULAP, Nazilerin çılgın eğlencelerle sadizmin orijinini kutladığ

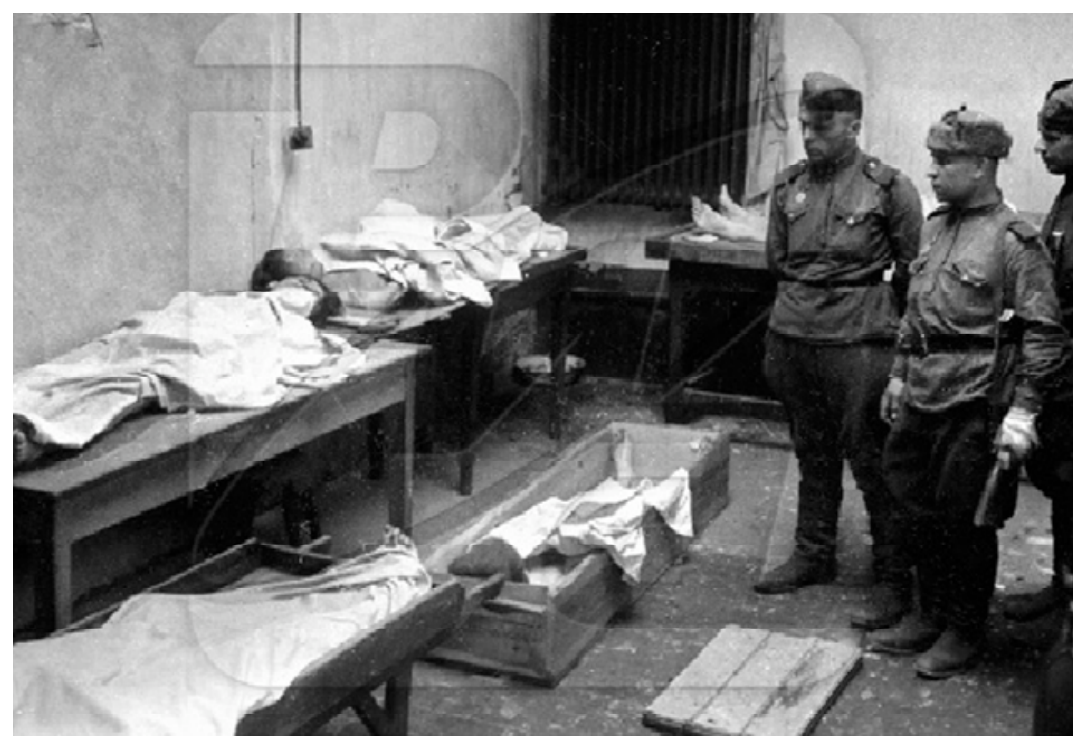

Resim: 6

yerdi. Sırtlarında kanlı kamçı izleriyle, işkence odalarından çıkarılan tutsakları gördüm.” Bir başka tanık olan Kurt Fischer ise şöyle der: "birçok sosyal demokrat kaçırılarak buraya getirildi; işkence ve tecavüzlerle öldürüldü. 1936 yılında, Berlin, Alman Havacılık Müzesi'nde eğlenirken, bir alt katındaki tutsaklardan habersizdi”, (URL-2).

II. Dünya Savaşı patlak verene kadar, tanınmış çok sayıdaki ünlü şair, yazar, devlet ve kilise adamı burada işkencelerle öldürülmüşlerdir. Bir zamanlar Almanya
II Almanya'da I. Dünya Savaşı'nın

ardindan, 1918 yilinda yaşanan deurimden sonra Karl Liebknecht ve Rosa Luxemburg önderliğinde silahlı ayaklanma

düzenleyen ve adı daha sonra Almanya

Komünist Partisi olan grubun ilk adı spartaküs Birliği'dir.
Resim: Müzesi maketi, Berlin Teknik Müzesi Resim: 6

Moabit Hapishanesi'nde 05.08.1945'e ait bir fotoğraf, RIA Novosti görsel arşivi, Kaynak: URL-3

$40 \mid$ sayı 13, 2012 
12 yarisma raporu bunu 'acupunctur effect' olarak tanımlamıştır.
Dışişleri Bakanlığı'nda önemli pozisyona sahip, aynı zamanda bir edebiyat adamı olan Albrecht Haushofer de, burada kaldı̆̆ bugün o bölgede yaşananlara 1ş1k tutmaktadır. Bu şiirler, 1945 yılında savaştan hemen sonra bulunmuş ve 1946 yılında "Moabit Soneleri” adıyla basılmıştır.

Hoş ve uzun zamanlardı, budalılığın kol gezdiği

Ve daha sonra, en güzel kafalardı asılan

»Es gibt wohl Zeiten, die der Irrsinn lenkt.

Dann sind's die besten Köpfe, die man henkt.«

II. Dünya Savaşı'nın ardından, savaş sırasında ağır bombardıman altında kalan bölgede hasar görmüş birkaç pavyon dışında birşey kalmamıştır. 1951 yılında alınan bir kararla, kalan bu birkaç pavyon da yıkılmıştır. Fakat duvara olan yakınlığ nedeniyle de bakımsız ve işlevsiz bir alana dönüşen bölge, bu dönemde gündüzleri çevredeki ofislerin otopark alanı, geceleri ise satıcılar ve hayat kadınlarının barınağı olarak kullanılmıştır (Kalcher ve Schröder 2009, 84-92)

1989 yılı, Berlin için bir milad gibidir. Duvarın yıkılmasının ardından, ortaya çıkan derin boşluklar, Berlin'i kendisiyle yüzleştirecektir. ULAP 'ta, Berlin'in, yıllar sonra yüzleştiği bu boşluklarından biridir. Çünkü, boşluklar, yalnız duvardan arta kalan kentsel izlerde değil, görsel ve dokunsal olarak temas ettiği heryerdedir. Dolayısıyla, Berlin'in birleşmesi, 1.3 hektar, üçgen biçimindeki ULAP Alanı'nı da, Reichstag Bölgesi ve ofis alanlarına olan yakınlığı nedeniyle, birden yeni kentsel merkez alanı içerisinde büyük bir boşluk olarak bırakmıştır.

Hükümetin yeni merkez alana ilişkin yaptığı planlama çalışmaları dahilinde ULAP alanı içerisindeki eski tren istasyonu Lehrter büyütülmüş, Berlin'in
Merkez İstasyonu olan Hauptbahnhof olmuştur. Fakat yaşanan ulaşım problemleri ve işlevsiz kalan alanları dolayısıyla, 2005 yılında bölgenin yeniden kente katılımına ve hayat bulmasına ilişkin bir yarışma açılması düşünülmüştür.

Yarışmayı, Dresden'li bir mimarlık ve peyzaj tasarım grubu olan "Rehwaldt Landschaftsarchitekten" kazanmıştır (URL1).

Kazanan projenin başarısı, "bölgenin dönüşümü sırasında, varolan durum ve potansiyelin değerlendirilerek, ufak tefek değişimlerle ${ }^{2 \mathbf{2}}$ estetik ve işlevselliğin bir araya getirilmesi ve bunun, geçmişin izlerinin sürülerek yapılması" olarak gösterilmiştir. Dolayısıyla projenin bu sosyal ve tarihsel duyarlılığı, ULAP Fuar Alanı'nın dönüşümü sırasında bölgenin kentsel ve kolektif belleğinin korunmasına ilişkin çabalarını göstermektedir.

\section{Proje}

2008 yılında başarıyla uygulanan proje, alanın varolan tüm özelliklerini bir potansiyel olarak görmüş ve her birini bir peyzaj ögesi olarak tasarımlarına dahil etmiştir. 'Landscape' Dergisi'nin 2011 bahar sayısında çıkan konuya ilişkin yazıda, projenin tasarımcısı Till Rehwaldt, 1879 yılından kalma ıhlamur ağaçlarının, yeni eklenenlerle birlikte oluşturduğu yeşil dokuyu bozmamanın, başlıca hedefleri olduğunu ve ULAP Meydanı'nın bu sayede ortaya çıktığını belirtiyor. Alanın kötü bir ünü olduğunu, daima karanlık, tehlikeli ve girilmeyen bir yer olarak anımsandığını ve çok basit, ekonomik çözümlerle bunun üstesinden gelebildiklerini açıklıyor.

Üçgen biçimli ve yol kotundan aşağıda yer alan proje alanının en göze çarpan özelliklerinden biri de, Naziler tarafından inşa edilmiş olan $20 \mathrm{~m}$. x $9.6 \mathrm{~m}$. olan iri 


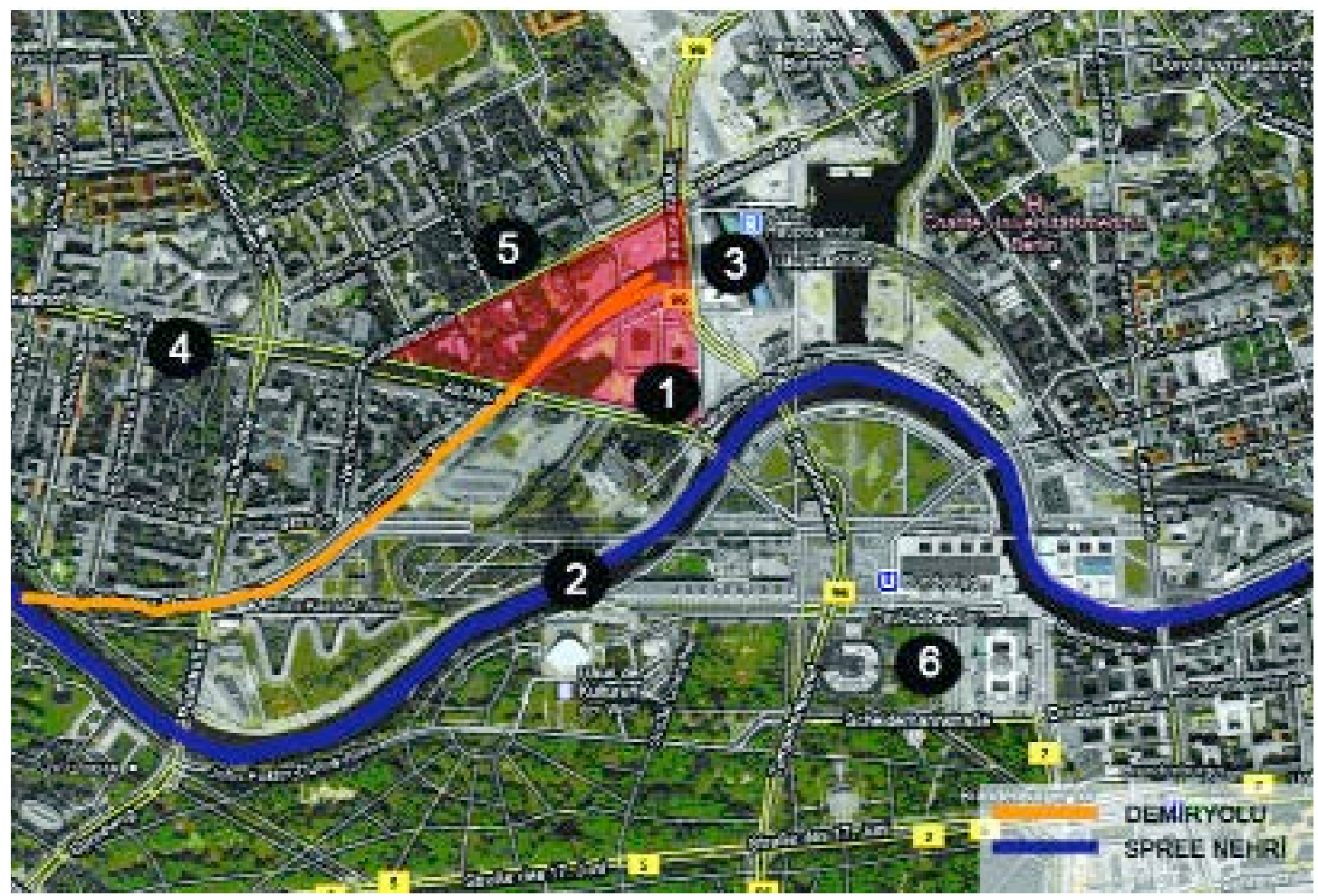

\author{
Resim: 7 \\ Proje alani \\ I.Ulap Platz Proje \\ Alanı 2.Spree Nehri \\ 3.Hauptbahnhof \\ (Berlin Merkez \\ istasyonu) \\ 4. Moabit \\ Hapishanesi (yıldiz \\ biçimli plan) \\ 5.Moabit \\ Hapishanesi Anı \\ Parkl \\ 6.Reichstag Bölgesi \\ Kaynak: URL-S, \\ http:/maps.google.c \\ om'dan alana ait \\ erişilen harita \\ üzerindeki bölgelere \\ numaralandirma ve \\ lejand yazara aittir. \\ Resim: 8 \\ Varolan basamak- \\ larin yanina \\ yapilan yeni \\ basamaklar
}

Resim: 7

merdivenlerin İkinci Dünya Savaş1

sırasında bombalandıkları haliyle korun-

muş olmasıdır. Rehwaldt, merdivenlerin

dörtte üçlük kısmına projede yer verdik-

lerini ve dörtte birlik kısmını da yeniden

yaptıklarını belirtiyor. Boş kaldığı

dönemde merdivenleri saran ağaç kökleri-

nine de böylelikle dokunmamış

olduklarını ekliyor.

Tren istasyonuna giden eski ulaşım aksı izine sadık kalarak yeniden yapılan yürüyüş hattı ve yeşil meydanıyla proje, hem topluca yapılan etkinlikler, hem de bireysel kullanımlar için uygun hale getirilmiş. Bu her detayı işlenmiş, fakat olduğu gibi korunmuş alan, neredeyse sadece varolanlarla, yerin ve üzerinden ürettiği kolektif belleğin korunmasını aynı zamanda da yeni bir deneyimi olanaklı hale getirmiştir.

Tasarımlarının bir diğer güçlü yanı ise,

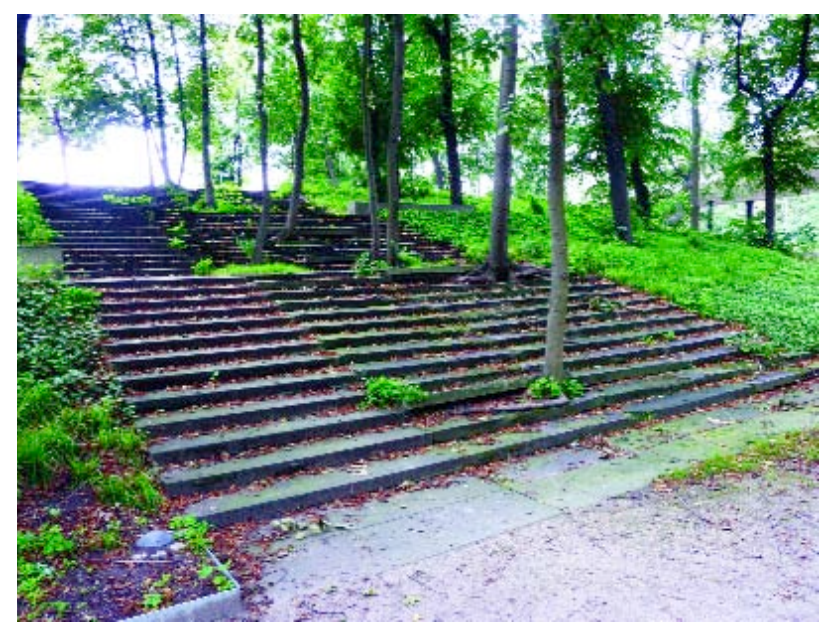

Resim: 8

varolanlarla, yeni yapılanları birarada kul-

lanırken, ince vurgularla, geçmişin izlerini özellikle belli etmesidir. Bunun en iyi örneği, ağaç köklerinin patlatmış olduğu taş basamakların olduğu gibi bırakılarak, yanında aynı ritmde yenisinin uygulanmış olmasıdır. Ağaç kökleri nedeniyle kırılan basamaklar ile yenilerini ayıran belli belirsiz hat, şimdi geçmiş ve bugünün birbirine 
Resim: 9

Varolan ă̆aç dokusunun korunmasına ilişkin bir

$$
\text { fotoğraf }
$$

Resim: 10

Eski ve yeni merdiveni ayıran

derz

Fotoğraf: Çalak, 20II

Resim: II

Ü̧gen parsel içerisindeki proje alanı. Sağdaki yürüyüş yolu,

Alt-Moabit Caddesi'ni, üst kottaki trenyolu viyadüğünün

kenarindan istasyona

bağlamaktadır.

Fotoğraf: falak, 20II

Resim: 12

Merkez istasyonu'na yaklaşım Fotoğraf: Calak, 201

Resim: 13

Parkın içinden görünüm, Fotoğraf: Çalak, 20II

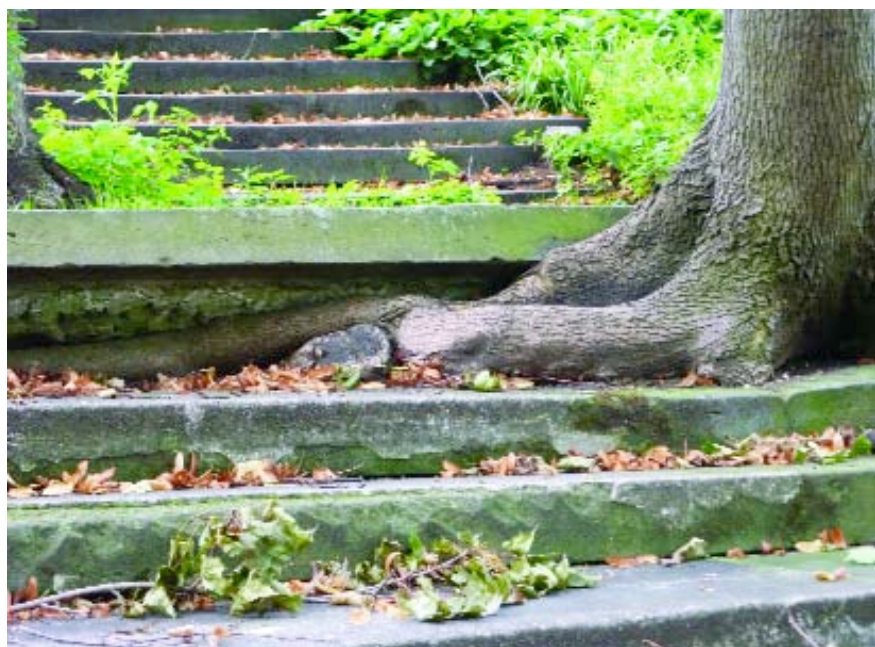

Resim: 9

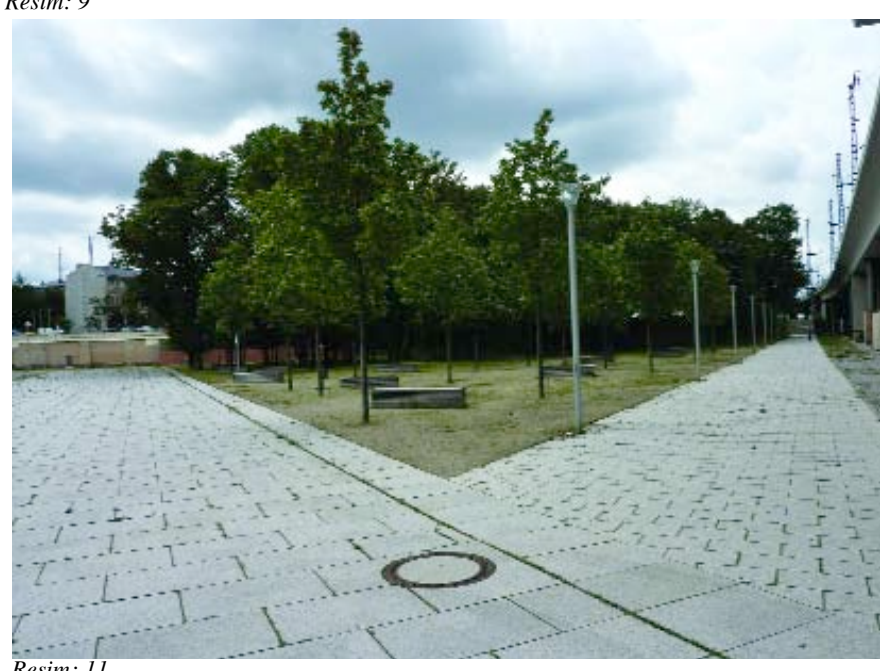

Resim: 11

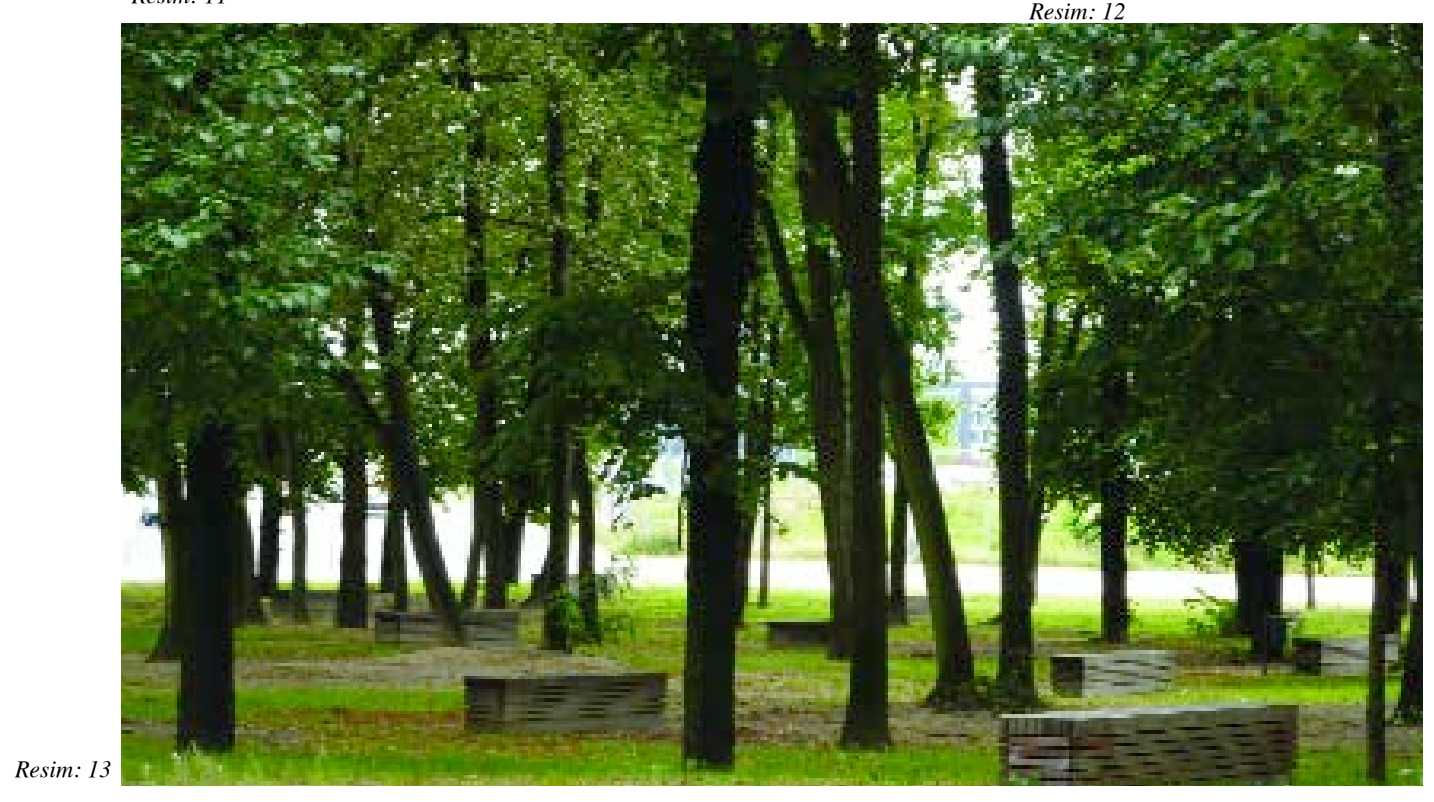

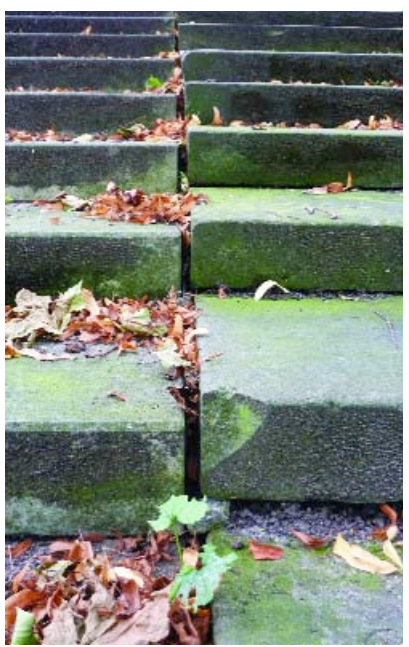

Resim: 10

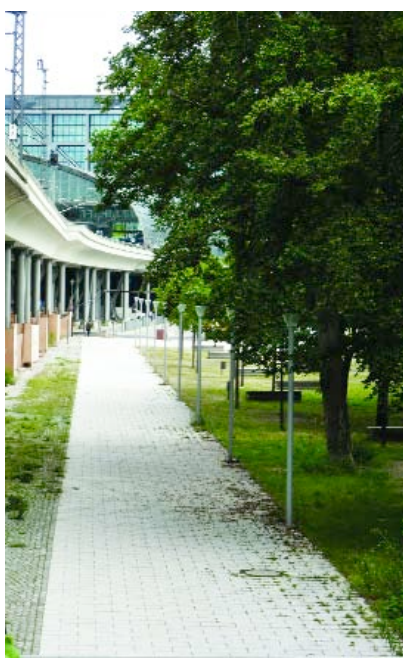

Resim: 12

Sayı 13, 2012 43 


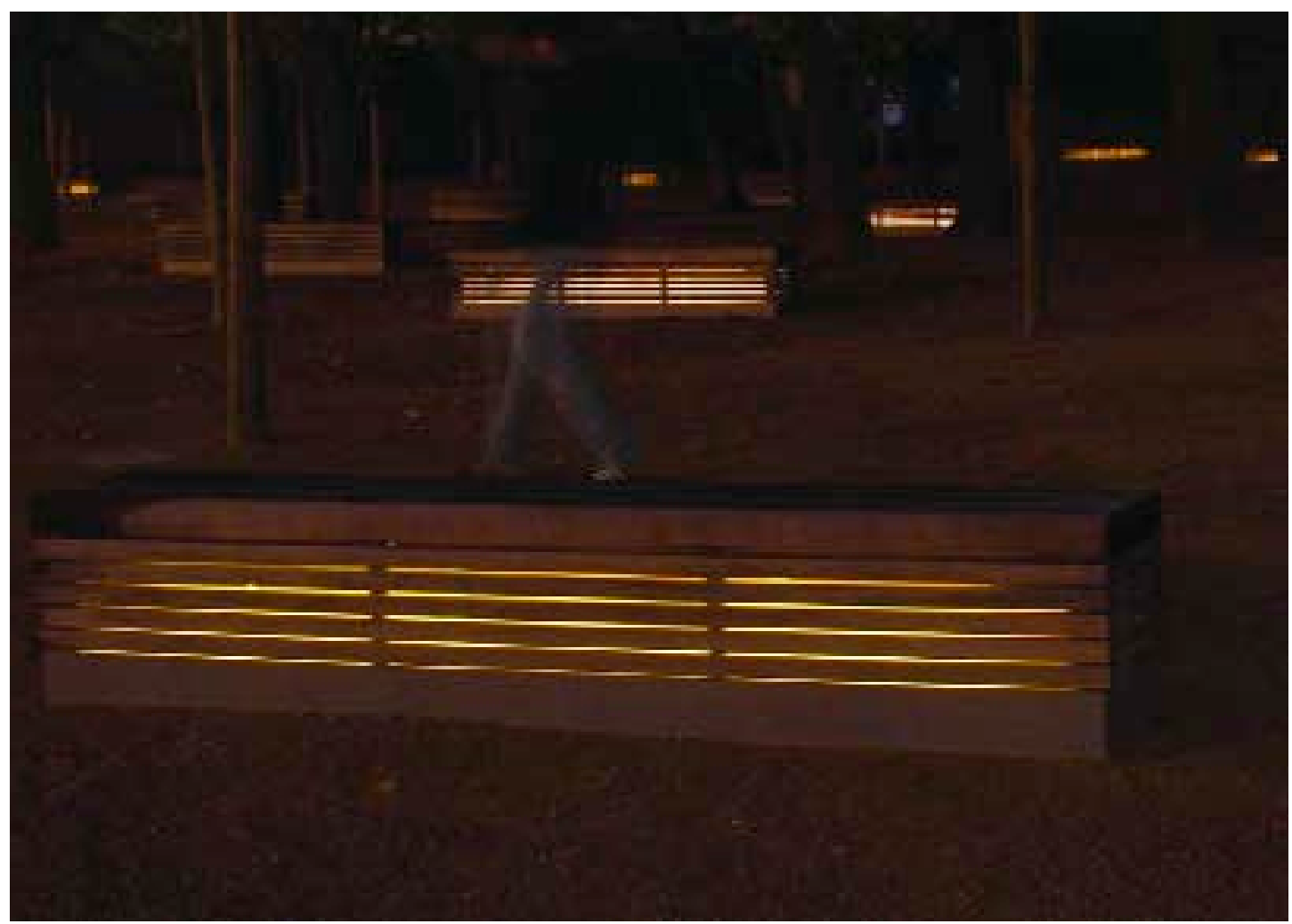

Resim: 14

değdiği yerdir.

Yeni tren yolunun yukarı alınarak alanın birleştirilmesi, yaya akışının bölünmesini engellemiş, bu yeni bütünsellik üzerinde tasarlanan yeni ULAP meydanı, çevre işyerlerinde çalışanların öğle tatillerinde kullandığ bir buluşma alanı olmuştur.

Ağaçlık alan içerisine yerleştirilen otuz iki adet ahşap bank, geceleri de birer 1şık kaynağı olarak kullanılmaktadır. Malzeme olarak tercih edilen ahşap, yaşayan ve dokunsal bir malzeme olmasının ötesinde, kalıcı bir anıt ve dondurulmuş bir tarihin aksine geçiciliği ve canlılığı da hatırlatmaktadır.

Bu topraklarda ölmüşlerin mezarlarını da andıran ve geceleri içlerinden çıkan 1 şıkla adeta kutsal birer tabuta dönüşen banklar, sessizce olanları anmaya ve yas tutmaya devam eder gibidir.
Ulap Meydanı Projesi, peyzaj

tasarımlarının, yapılı çevre ile o çevreyi yaşayan insan arasında bağ kurabilme potansiyelini gösteren bir örnek olarak da değerlendirilmelidir.

\section{Bellek Peyzajlart}

21. yy.'da mekan ve zamana dair değişen parametreler, algılarımızda 'geçmiş', 'uzaklık' gibi kavramlara ait değişimleri de beraberinde getirmiştir. Bedensel değil, zihinsel olarak algılamaya çalıştığımız dünya, bizi somuttan, soyut bir zemine doğru taşımaktadır. Halbuki, etrafımızda kurduğumuz somut dünya, bizi biz yapan değerleri ve bu değerler içerisinde 'biz'i tanımlamaktadır. Sessiz ve hareketsiz nesneler, binalar, bizim onları yaptığımız şekilde ve yaptığımız yerdedirler. Dolayısıyla hem yaşam biçimimizi hem de anlam dünyamızı temsil ederler. $\mathrm{Bu}$
Resim: 14

Gece aydinlatilan

ahşap banklar Kaynak: URL-I 
13 Geleneksel anitlaştırma

söylemine tepki olarak gelisen bu söylem, "demokratik-anit", "antianıt" gibi pek çok isimle de anilmaktadır. Ancak, güncel dilde en çok James Edward Young'in ilk olarak ortaya attığı "karşı-anit" terimi kullanilmaktadir. Terimin ilk kullanıldı̆̆ı kaynak için bkz: young, J. Edward. 1992. The Counter-Monument: Memory Against Itself in Germany Today. Critical Inquiry. 267-296. anlamda 'biz'e dair birçok değeri, anıyı da karmaşık bir biçimde birarada taşırlar. Önemli olan, bu çok katmanlı yap1 içerisindeki parçaların kendine özgü bir ilişki zinciri olduğunu bilmek ve bu kendine özgü sürekliliğinin önemini farkedebilmektir. Bu, kenti özgün kılan belleğinin de süreklilik izidir. Ancak bu süreklilik korunabildiği ölçüde üzerinden kurulabilen bir kolektif bellekten ve onun sürekliliğinden bahsedilebilecektir.

"Kentlerin dönüşüm dönemleri o kentlerde kalıcı izler bırakır. Katmanların iyi korunmas1, bu izlerin takibine ve kentsel mekanın, kentin belleğini nasıl şekillendirdiğinin anlaşılmasına olanak sağlar" (Bilsel, 2004). Savaşlar ya da politik kararlar sonucunda oluşan kentsel dokudaki yıkımlar, parçalanmalar ya da radikal değişimler ise kentin belleğinde önemli kopukluklara neden olabilmektedir. ULAP'ta olduğu gibi bazen bu kopukluklar özellikle vurgulanmakta dolayısıyla bu kırılmaların sosyal ve kentsel çevrede bıraktığı izin altı çizilmektedir. Dolayısıyla da tahribat özellikle vurgulanmış olmaktadır. Fakat sonuçta, artık savaşların ardından kutsanan 'kahramanlar' ya da kazanilan 'zafer' değil, 'barış’tır. Unutulmaması gereken, her savaşın, sonucu galibiyet ya da mağlubiyet olsun, bir savaş olduğu ve istisnasız yeryüzüne yas, keder ve acı getirdiğidir. Dolayısıyla artık hatırlanacak ya da unutturulmaması sağlanancak imgesel, simgesel anitlar da yoktur. Artık geçmişin izlerini, yaşanılan acıları hatırlatacak ve onlarla yüzleştirecek 'bellek peyzajları', 'bellek mimarileri' vardir.

Dünyada 1980'lerden sonra görülmeye başlanan bu söylemler, özellikle Berlin Duvarı'nın yıkılışının ardından daha çok görülür, örneklenir olmuştur. 19. yy. ve
20. yy.' da daha çok anitlarla ya da abidevi yapılarla yüceltilen zafer ve hükümranlık fikri, savaşlarla dolu 20. yy. sonrası süreçte artık anlamlandırılması zor bir hale gelmiştir. Bu yeni söylem, akademik çevrelerce karşı-anıt (countermonument) adı ile tariflenmektedir'3 .

Vietnam Gaziler Anıtı'nın tasarımcısı Maya Lin (1995, 68)'e göre anti (karş1)anıtlar, geleneksel anıtların tersine izleyiciye deneyim mekânları sunmaktadırlar.

Benzer bir şekilde soykırım tarihçisi James Edward Young (1999, 1-15) da geleneksel anıtların didaktik bir hatırlama süreci ile izleyiciyi pasifleştirdiğini, karş1anıtların ise izleyiciyi andığı olay hakkında derin düşünceye dalmaya davet ettiğini söyler. Young $(1999,96)$ ayrıca "anti-kahramancı, çoğunlukla ironik kavramsal tasarımlar" içeren karşı-anıt söylemi özellikle "geç on dokuzuncu yüzyılın kahramancı, kendi itibarını yükselten figüratif ikonlarına" bir tepki olarak görülebileceğini belirtir. Mimarlık tarihçisi ve yazarı Hélène Lipstadt $(1999,68)$ ise, geleneksel anıtı objeleşen, kahramancı, ölümü öven ve yanıltıcı bir kalıcılık illüzyonu olarak, kaşı-anıtı ise yerleşen, anti-kahramancı, savaşın korkunç yüzünü göstermeyi amaçlayan fakat kendi gelipgeçiciliği konusunda aldatmayan bir oluşum olarak tanımlamaktadır (aktaran Yllmaz, 2008).

20. yüzyılın yaklaşık son otuz yılını kapsayan zaman dilimi, her iki söylemin de örneklerini görmenin mümkün olduğu bir dönemdir. Geleneksel anıt söyleminin pratiklerinin sıklıkla tekrar edildiği bir dönem olsa da, Ulap Platz'da gerçekleştiği gibi karşı-anıt söylemiyle, belleği deneyimlenir kılarak, mekansal ve sosyal olarak sürekliliği sağlayan örnekler de verilmektedir. Modernizmin evrensel ve 
tekrarlanan, benzeştirici eğilimlerinin çok tartışıldığı günümüzde, ardına kentin sosyal ve politik tarihini de alarak yaptığ 1 şehir okuması, bu anlamda Ulap Platz'da gerçekleştirilen projeyi bugünkü başarısına taşımıştır. 20. yüzyıl ertesinde hızla kabuk değiştiren tüm büyük metropollerde sıkça işlenen, ortak özelliklerin, birbirine benzer üretimlerin yanısıra, Ulap Platz gibi evrensel/tarihsel bir bağlam içerisinde değerlendirilmiş, dolayısıyla özgün bakış açılarının da olabileceğini görmek sosyal ve mekansal süreklilik bağlamında kentler için umut vericidir.

Mumford (2007, 683-692), kentlere ilişkin bir yorum getirebilmek için, kentteki mekansal biçimlerin "oluşturulması ve dönüştürülmesi"ne ilişkin mekanizmaları kavramak gerektiğinden bahseder. O'na göre kente, toplumsal süreçle mekansal biçimlerin sürekli etkileşim halinde olduğu bir sistem olarak bakmak gerekmektedir. Fakat bu makalede anlatmak istenilen, bu etkileşime kent kurgusunun zaman içerisindeki değişiminin de dahil olması gerektiğidir. Ayrıca bu etkileşim ağ1 içerisindeki süreklilikten bahsedebilmek ya da sürekliliğin sağlanabilmesi yolunda mekansal bir öneri geliştirebilmek için de tasarımcının, onu mekansal, toplumsal ve tarihsel; anlamlı bütünlüğü içinde okuması, bu bütünlüğü okurken de yalnızca o yerin değil, heryerin bilgisine açık olması ve bunlar arasında ilişkiler kurabilecek yetiye sahip olması gerektiğidir

Biçimin şehirde izini bıraktığı süreç, şehrin tarihidir; olaylar dizgesi ise kentin kolektif belleğini oluşturur. Kentin ruhu kentin tarihinde yatar; bu ruh bir kez biçim kazandı ̆̆ında, bir yerin göstergesi haline gelir. 'Bellek', onun yapısının kllavuzu olur.” (Eisenmann
2006, 163-177).

\section{KAYNAKÇA}

Adorno, T. 1991. The Culture Industry: Selected Essays on Mass Culture. ed.Bernstein, J.M. London: Routledge, 52-54.

Amin, Ash. 2010. Collective Culture and Urban Public Space. Urban Diversity: Space, Culture, and Inclusive Pluralism in Cities Worldwide. ed. Kihato C.,Massoumi M. \& Ruble B., 21- 51 Baltimore: John Hopkins University Press.

Bergson, Henri. 2007. Madde ve Bellek. Ankara: Dost Yayınevi.

Bilgin, İhsan. 1995. Şehir Mimarisi. Arredamento Mimarlık. İstanbul: Boyut Yayıncılık.

Bilsel, Cana. 2006. Yeni Dünya Düzeninde Çözülen Kentler ve Kamusal Alan. Mimarlık Dergisi 32. Ankara: Mimarlar Odası Yayınları.

Boyer, Christine. 1998. The City of Collective Memory. Cambridge: MIT Press.

Castells, Manuel. 2008. Kimliğin Gücü, Enformasyon Çağı: Ekonomi, Toplum ve Kültür, İstanbul: Bilgi Üniversitesi Yayınları.

Connerton, Paul. 2009. How Modernity Forgets. Cambridge: Cambridge University Press.

Eisenmann, Peter. 2006. Amerikan Basımı İçin Editörün Sunuşu, ed. A.Rossi. Şehrin Mimarisi. İstanbul: Kanat Yayıncılık.

Erkmen, Alev. 2010. Geç Osmanlı Dünyasında Mimarlık ve Hafıza. İstanbul: Akın Nalça Kitapları.

Gökgür, Pelin. 2008. Kentsel Mekanda Kamusal Alanın Yeri. İstanbul: Bağlam Yayıncılık.

Halbwachs, Maurice. 1992. On Collective Memory. trans. Lewis A. Cosner. Chicago (IL): University of Chicago Press.

Huyssen, Andreas. 1995. Alacakaranlık Anılan: Bellek Yitimi Kültüründe Zamanı Belirlemek. İstan bul: Metis Yayınları

Kalcher ve Schröder 2009. Landscape as a System: Contemporary German Landscape Architecture. Birkhäuser Verlag AG.

Kirshenbaum, Binnie. 2004. Hester Yıkıntılar Arasında. İstanbul: Agora Kitaplığı.

Lefebvre, Henri. 2003. The Writings On Cities. Oxford: Blackwell Publishing.

Levi, Primo. 1996. Boğulanlar Kurtulanlar. İstanbul: Can Yayınları.

Lin, Maya. 1995. Grounds for Remembering: Monuments, Memorials, Texts. Occasional Papers of the Doreen B. Townsend Center for the Humanities. Berkeley: Doreen B. Townsend Beşeri Bilimler Merkezi.

Lipstadt, Hélène. 1999. Learning from Lutyens: Thiepval in the Age of the Anti-Monument. Harvard Design Magazine. (9): 68.

Madanipour, Ali. 2010. Whose Public Space. Oxon: Routledge Publishing.

Misztal, Barbara. 2003. Theories of Social Remembering. Philedelphia: Open University Press.

Mumford, Lewis. 2007. Tarih Boyunca Kent. İstanbul: 
Ayrıntı Yayıncilık

Musil, Robert. 1998. Monuments. Selected Writings. ed. Burton Pike. London and New York:

Continuum, 320

Nora, Pierre. 2006. Hafiza Mekanları. Ankara: Dost Yayınlar1.

Pearson, Rick. 2011. Project Profile: Ulap Platz in Berlin and Carl-Alexander in Baesweiler, The Journal of Landscape Institute, 8-15.

Schubert, Dirk. 1995. Modern'e Uzanan Yollar: Hamburg'ta Konut ve Plan, Arredamento Mimarlık. İstan bul: Boyut Yayıncılık.

Tanyeli, Uğur. 2010. Türkiye' nin Görsellik Tarihine Giriş. İstanbul:Metis Yayıncılık.

Yalım, İnci.2001. Ulus Square as a Representational Form of Collective Memory (Toplumsal Belleğin Temsili Biçimi Olarak Ulus Meydanı). ODTÜ, Yayımlanmamış Y.L.Tezi

Yalım, İnci, 2009, "Ulus Devletin Kamusal Alanda Meşruiyet İhtiyacı: Toplumsal Belleğin Ulus Meydanı Üzerinden Kurgulanma Çabası. Ankara' nın Kamusal Yüzleri. der.Güven Arif Sargın. İstanbul: İletişim Yayınları, 157-214.

Yılmaz, Ahenk. 2008. Anıtlaştırma Söyleminin Dönüşümü: Gelibolu Savaşı'nı (Karşı)-Anıtlaştırmak. Mimarlık Dergisi 341. Ankara: Mimarlar Odası Yayınlar1.

Young, J. Edward. 1992. The Counter-Monument: Memory Against Itself in Germany Today. Critical Inquiry, 267-296.

Young, J.Edward. 1999. Memory and Counter-memory: The End of the Monument in Germany. Harvard Design Magazine (9): 1-15.

URL-1. http://www.publicspace.org. 13.04.2012

URL-2. http://www.berlinstreet.de/2023. 13.04.2012

URL-3, www.russianarchive.com. 13.04.2012

URL-4, http://www.dailysoft.com/berlinwall/maps/berlinwallmap_02.htm. 13.04.2012

URL-5, http:/maps.google.com. 13.04.2012 